College of William \& Mary Law School William \& Mary Law School Scholarship Repository

2011

\title{
Book Review of Intellectual Property and Human Development: Current Trends and Future Scenarios
}

Benjamin J. Keele

bkeele@iu.edu

\section{Repository Citation}

Keele, Benjamin J., "Book Review of Intellectual Property and Human Development: Current Trends and Future Scenarios" (2011). Library Staff Publications. 36.

https://scholarship.law.wm.edu/libpubs/36

Copyright c 2011 by the authors. This article is brought to you by the William \& Mary Law School Scholarship Repository. https://scholarship.law.wm.edu/libpubs 
Intellectual Property and Human Development: Current Trends and Future Scenarios. Edited by Tzen Wong and Graham Dutfield. Cambridge:

Cambridge University Press, 2011. Pp. L, 397. ISBN: 978-0-521-19093-0 (hbk), 978-0-521-13828-4 (pbk). UK £60.00 (hbk), £19.99 (pbk); US $\$ 95.00$ (hbk.), \$32.99 (pbk).

When asked about the effects of intellectual property laws on their lives, citizens of developed countries might mention patents as the reason they cannot buy generic versions of the medicines they need, or copyright as the reason some popular movies and musical works are not available on YouTube. They are not likely to list development of medicines for neglected diseases or commercial appropriation of traditional knowledge and crafts of indigenous peoples. This book will expand the reader's understanding of the tangible effects intellectual property laws have on people's lives.

Approaching intellectual property from a human development perspective, each chapter examines a different area of intellectual property and discusses how the relevant laws expand or contract people's capabilities to lead fulfilling lives. This approach is multidisciplinary and adopts an expansive view of human development to include access to health, education, food, and culture. Each type of intellectual property affects human 
development. Patents can be used to prevent the production and importing of generic drugs, which makes the drugs more expensive and less accessible in developing nations. Food security can be undermined due to patents on genetically modified crop seeds. Copyright can hinder the transfer of knowledge by keeping educational textbooks and scholarly journals too costly for developing nations. One can certainly make arguments to defend these uses of intellectual property, but this book suggests that human development was not adequately considered when intellectual property rules were devised.

Just as human development concerns are posed as alternatives to the economic incentive justification for intellectual property, additional models of intellectual property are presented. Traditional knowledge and cultural expressions present especially difficult cases that challenge the Western dichotomy between works that are proprietary and those that are in the public domain and have no legal protections whatsoever. While it may seem reasonable that indigenous peoples should have some control over and receive some benefit from cultural traditions passed down through generations, developing legal mechanisms to protect these intangible goods, whether by familiar intellectual property mechanisms or sui generis rights, is challenging. These are just a few examples of the intellectual property regimes described in the book.

This edited volume contains nine chapters and five appendices. Patent and copyright law each receives about equal attention, while trademarks receive less, but still substantial, coverage. The book is decidedly international in scope; the authors hail from a wide range of countries, and a variety of national and regional laws and multilateral treaties are discussed. This book provides an excellent orientation to international copyright law and its focus on human development contextualizes the material and keeps it from becoming too abstract. The bibliographies are comprehensive and will be a valuable source for literature reviews for quite some time.

I highly recommend this book for any academic collection in intellectual property law or even international law generally. One minor complaint, which is directed more at academic publishing in general than at this specific book, is that the extensive bibliographies contain a number of URLs that are not likely to survive very far into the future. For instance, many of the citations to law journal articles contain URLs from the Social Science Research Network, when URLs from the journals' own websites would probably be more dependable. Complete bibliographic information is given such that a diligent researcher should be able to eventually retrieve the source, 
so the URLs should only be regarded as supplemental. On the whole, this book will be a great resource for scholars and policymakers.

Benjamin Keele

Reference Librarian

William \& Mary Law Library

Williamsburg, VA USA 